\title{
SINERGI ZAKAT DAN PAJAK SEBAGAI SOLUSI PERBAIKAN EKONOMI INDONESIA
}

Alan Hidayat ${ }^{1)}$ dan Elis Teti Rusmiati2)

1) 2)Dosen Universitas Prof. Dr. Moestopo (Beragama), Jakarta

1)alan.hidayat@dsn.moestopo.ac.id

2)elistetirusmiati@dsn.moestopo.ac.id

\begin{abstract}
Abstrak
Pajak merupakan instrumen yang penting dalam kehidupan bernegara. Seluruh kebutuhan pembangunan negara, baik pembangunan infrastruktur, belanja subsidi, dan kebutuhan belanja pegawai, dibayar dengan uang pajak. Zakat juga memiliki peran yang hampir sama dengan pajak. Di Indonesia dengan mayoritas penduduknya beragama Islam, pengelolaan zakat memiliki potensi ekonomi yang cukup besar bagi negara. Jika sinergi pajak dan zakat terbangun dengan baik, akan mampu menjadi solusi bagi perbaikan ekonomi di Indonesia. Paper ini bertujuan untuk menganalisis sinergi pajak dan zakat, yang dikaitkan dengan peraturan pemerintah tentang zakat sebagai pengurang wajib pajak.
\end{abstract}

Kata Kunci: zakat, pajak, sinergi, peraturan pemerintah

\begin{abstract}
Tax is an essential instrument in a nation's life. All of the nation's development needs, such as infrastructure building, subsidy expenditure, employee expenditure need, are paid with tax money. Zakat also has similiar role with tax. In Indonesia with Islam as the majority of religion, zakat management has a massive economic potential for the nation. A well created Synergy between tax and zakat could become a solution in improving economy in Indonesia. This paper aims to analyze the synergy between tax and zakat, which is associated with government regulations about zakat as taxpayer alleviation.
\end{abstract}

Keywords: zakat, tax, synergy, government regulations

\section{PENDAHULUAN}

Di Indonesia dengan mayoritas jumlah penduduknya muslim, zakat memiliki potensi ekonomi yang cukup besar. Hanya saja, teknis menghimpun dan tata kelolanya belum maksimal. Di sisi lain, umat muslim juga mempunyai kewajiban membayar pajak sebagai bentuk ketaatan terhadap peraturan negara. Dua bentuk kewajiban ini memunculkan masalah karena mengakibatkan dua kali pengeluaran yang harus disisihkan dari penghasilan. Selain itu, dua jenis kewajiban juga memberi kesan bahwa urusan agama benar-benar terpisah dari urusan negara.

Ketaatan wajib pajak yang rendah sering dikeluhkan pemerintah padahal sumber pendapatan untuk pengelolaan negara sebagian besar diambil dari pajak. Pengelolaan zakat juga sering dipersoalkan karena dinilai tidak maksimal. Jika saja tata kelolanya optimal, pajak dan zakat memiliki potensi ekonomi yang sangat besar baik bagi pembangunan masyarakat maupun negara.

Paper ini bertujuan untuk menganalisis sinergi pajak dan zakat, yang dalam perannya memiliki titik singgung yang sama. Pembahasan juga akan dikaitkan dengan peraturan pemerintah tentang pengelolaan zakat, di mana zakat bisa sebagai pengurang wajib pajak.

\section{TINJAUAN PUSTAKA}

Zakat adalah suatu kewajiban bagi seorang muslim dalam bentuk mengeluarkan sebagian harta yang dimilikinya jika telah sampai pada batas minimal (nisab). Bagi umat Islam yang telah memenuhi persyaratan sebagai wajib zakat maka harus menunaikannya sebagai salah satu pelaksanaan Rukun Islam.

Lembaga yang berwenang melakukan tugas pengelolaan zakat ialah Badan Amil Zakat Nasional (BAZNAS). Untuk membantu BAZNAS, dalam pelaksanaan pengumpulan, pendistribusian dan pendayagunaan zakat, 
masyarakat dapat membentuk Lembaga Amil Zakat (LAZ), melalui izin Menteri atau pejabat yang ditunjuk oleh Menteri.

Distribusi zakat sebagaimana yang tertulis di dalam Al Quran Surat At-Taubah ayat 60, meliputi: 1) Fakir yaitu orang yang sangat kekurangan, kondisinya sangat miskin, juga tidak mempunyai pekerjaan; 2) Miskin yaitu orang yang tidak mempunyai harta benda dan serba kekurangan. Penghasilannya tidak cukup untuk memenuhi kebutuhan pokoknya (kebutuhan primer); 3) Amil Zakat adalah orang yang bekerja dalam pengumpulan zakat dan pendistribusiannya. Amil zakat berhak memperoleh bagian sesuai dengan ketentuan yang didasarkan dengan kompetisi pekerjaannya; 4) Muallaf yaitu orang yang baru masuk Islam namun masih lemah; 5) Riqab (budak/hamba sahaya); 6) Gharim, yaitu orang yang mempunyai utang dan tidak memiliki bagian lebih dari utangnya, baik atas utang untuk kemaslahatan dirinya maupun kemaslahatan masyarakat; 7) Fi Sabilillah adalah orang yang "berperang" di jalan Allah secara sukarela, atau orang yang berjuang menegakkan ajaran agama; 8) Ibnu Sabil, adalah orang atau musafir yang bepergian jauh dalam rangka mencari kemaslahatan umum yang manfaatnya kembali bagi agama Islam.

Jika mengikuti beberapa terminology yang disampaikan para ahli, zakat memiliki terminologi ekonomi yaitu sebagai sarana untuk memperlancar distribusi dan menstabilkan konsumsi dalam kehidupan masyarakat.

Tujuan menyejahterakan rakyat ini juga tertuang dalam alinea ke-4 Pembukaan UUD Negara Republik Indonesia Tahun 1945. Salah satu instrumen yang digunakan oleh Negara untuk kepentingan itu ialah pajak. Dalam Undang-Undang nomor 28 Tahun 2007 pasal 1 disebutkan bahwa pajak adalah kontribusi wajib kepada negara yang terutang oleh orang pribadi atau badan yang bersifat memaksa berdasarkan UndangUndang, dengan tidak mendapatkan imbalan secara langsung dan digunakan untuk keperluan negara bagi sebesar-besarnya kemakmuran rakyat.

Dari sini terlihat bahwa zakat dan pajak memiliki hakikat tujuan yang sama yakni untuk menyejahterakan masyarakat.

\section{METODE PENELITIAN}

Metode kajian yang dipakai dalam paper ini ialah studi pustaka (Library research). Dalam studi pustaka ini dilakukan kegiatan kajian teoritis, referensi serta literatur ilmiah lainnya yang berkaitan dengan budaya, nilai dan norma yang berkembang pada situasi sosial yang diteliti. Selain studi pustaka juga melakukan observasi lapangan (Field research) terhadap: wajib zakat dan pajak, penerima (mustahik) zakat dan lembaga penerima/pengelola zakat baik Badan Amil Zakat Nasional (BAZNAS)/Lembaga Amil Zakat (LAZ) maupun beberapa masjid.

\section{HASIL DAN PEMBAHASAN}

\section{Mereposisi Wajib Pajak oleh Zakat}

Selama ini umat Islam di Indonesia memiliki dua kewajiban: membayar pajak dan juga zakat. Zakat merupakan kewajiban agama yang mutlak, sedangkan pajak merupakan kewajiban dari negara _di mana ketaatan pada negara juga diperintahkan dalam ajaran agama. Dengan kewajiban ganda ini terlihat bahwa terjadi dua kali pengeluaran dari penghasilan/pendapatan yang harus dikeluarkan. Di sisi lain, kewajiban membayar zakat yang terpisah atau dibedakan dengan membayar pajak itu, memunculkan kesan bahwa urusan agama benar-benar terpisah dari urusan negara. Walaupun memang Indonesia bukan negara agama tetapi pemisahan secara mutlak itu mengesankan ketidakpedulian negara terhadap urusan agama.

Untuk mengatasi beban ganda itu dilakukan upaya titik temu antara pajak dan zakat sehingga kedua kewajiban tersebut dapat dilaksanakan oleh umat Islam tanpa memberatkannya. Pemerintah telah melakuklan upaya di antaranya melalui Undang-undang No 23 tahun 2011 tentang Pengelolaan Zakat. Dalam pasal 22-23 UU tersebut dijelaskan bahwa zakat yang dibayarkan, dikurangkan dari penghasilan kena pajak, atau bahwa bukti setoran zakat dapat digunakan sebagai pengurang penghasilan kena pajak, atau dikenal sebagai tax deductable.

Pasal 22-23 Undang-undang No 23 tahun 2011 tentang Pengelolaan Zakat ini, oleh Elis Teti Rusmiati dan Alan Hidayat (2018) diterjemahkan dengan istilah 
"mereposisi". Dalam penelitiannya tentang "Mereposisi Kesadaran Wajib Pajak Melalui Wajib Zakat di Indonesia", berargumen bahwa kesadaran wajib zakat tumbuh secara signifikan, berbeda dengan wajib pajak. Dalam masyarakat religius khususnya di Indonesia, dorongan menjalankan aturan agama lebih kuat/lebih diutamakan dibandingkan aturan negara. Pada kondisi di mana jumlah penduduk Indonesia mayoritas beragama Islam, memasukkan unsur zakat sebagai umpan penyemangat (pendorong) wajib pajak, sangat tepat dilakukan. Dengan demikian, mereposisi atau menempatkan kembali kesadaran wajib pajak melalui wajib zakat, bisa efektif dilakukan.

Mereposisi dalam hal ini bisa bermanfaat ganda yaitu: mendorong/memberi semangat kepada wajib zakat karena zakat yang dibayarkan akan mengurangi penghasilan kena pajak, di sisi lain sekaligus mendongkrak tingkat kepatuhan wajib pajak melalui zakat yang dibayarkan.

Reposisi pajak oleh zakat yang terkandung dalam semangat UU Nomor 23 Tahun 2011 tentang Pengelolaan Zakat ini, pada kenyataan di lapangan tidak terimplementasi dengan baik. Terbukti masih banyak masyarakat yang tidak mengetahuinya. Masyarakat yang sudah paham pun banyak yang tidak memanfaatkan keringanan dari UU itu. Di antara beberapa masalah yang menjadi kendalanya, yang disebutkan dalam penelitian itu ialah: 1) Sosialisasi tidak maksimal; 2) Pembayaran zakat sering dilakukan di masjid-masjid atau bahkan diberikan langsung kepada mustahik (pihak penerima zakat), sehingga tidak memiliki bukti setoran resmi dari LAZ/BAZNAS, padahal bukti ini harus dilampirkan dalam SPT tahunan; 3) nilai zakat yang dibayarkkan tidak signifikan mengurangi pajak, sehingga menyebabkan masyarakat enggan melampirkan bukti setor zakat pada SPT tahunan mereka; 4) efektivitas dan efisiensi dalam proses pembayaran zakat sebagai pengurang penghasilan kena pajak belum maksimal.

\section{Integrasi Pajak dan Zakat}

Berdasarkan hasil penelitian bahwa banyak kendala yang muncul pada konsep reposisi sebagaimana yang dijelaskan tadi maka sudah selayaknya bahwa zakat bisa dijadikan sebagai pengurang pajak, bukan sekadar sebagai pengurang penghasilan kena pajak. Dengan kata lain, reposisi harus sekaligus dimaknai integrasi. Dasarnya adalah karena Pajak dan Zakat memiliki banyak kesamaan.

Ketua Umum Baznas 2004 - 2015, KH Didin Hafiduddin (2002) berpandangan bahwa usulan zakat sebagai pengurang pajak penting direalisasikan, sebab kedua instrumen tersebut memiliki kesamaan yakni untuk kepentingan bersama. Karenanya bisa saling mendukung tanpa harus menjadi beban ganda bagi muslim di Indonesia. Seandainya potensi zakat digali secara maksimal dengan dorongan pemerintah, maka dalam program pengentasan kemiskinan, pemerintah tidak perlu berhutang ke luar negeri karena hanya dari zakat profesi saja dalam setahun bisa mencapai triliunan rupiah.

Menurut Didin, tentang zakat sebagai pengurang pajak ini menjadi masalah krusial dalam pembahasan amandemen UU No.38 Tahun 1999 tentang Pengelolaan Zakat. Perdebatan mengenai hal ini mengarah pada dua arus utama; 1) Kelompok yang mendukung kebijakan zakat sebagai penghasilan bruto wajib pajak (tax deductible), seperti yang selama ini berjalan; 2) kelompok yang mendukung kebijakan zakat sebagai pengurang pajak secara langsung (tax credit).

Argumen yang mendukung kelompok kedua ini: 1) Perspektif keuangan negara: Ketika ada proses sinergi dan integrasi zakat pada kebijakan fiskal, maka akan ada sejumlah manfaat yang akan didapat, yaitu perluasan basis muzaki dan wajib pajak, serta membantu meringankan beban APBN dalam hal anggaran pengentasan kemiskinan. Melalui koordinasi yang baik antara otoritas zakat dengan otoritas pajak, maka identifikasi wajib zakat (muzaki) dan wajib pajak akan semakin luas, sehingga diharapkan pendapatan pajak dan zakat akan semakin meningkat. 2) Perspektif distribusi ekonomi; bahwa zakat diyakini akan menjadi alat redistribusi ekonomi yang efektif, di mana ia menjamin aliran kekayaan dari kelompok kaya kepada kelompok miskin. Dengan ini akan terbangun pertumbuhan ekonomi yang equal (merata). Secara ekonomi, aliran kekayaan dalam 
zakat ini juga akan mampu memberikan multiplier effect yang sangat besa serta pertumbuhan ekonomi yang lebih tinggi lagi. Konsep Integrasi pajak dan zakat ini juga sebenarnya sudah lama ditawarkan Masdar F. Mas'udi dalam Agama Keadilan (1991). Menurutnya, pemisahan lembaga zakat dan pajak adalah suatu hal yang sesat dan menyesatkan karena konsep zakat merupakan konsep pajak. Zakat identik denganruhnya dan pajak sebagai badannya. Zakat dan pajak ibarat raga yang bersamasama embodied. Jadi, bagi Muslim, pajak berfungsi sebagai zakat, maka bagi nonMuslim pajak itu adalah pajak.

Umat Islam yang telah membayar pajak, menurut Masdar tidak wajib lagi membayar zakat. Hal itu kalau pajak yang dibayarkan itu telah diniatkan sebagai zakat. Hal ini karena secara batin zakat adalah komitmen spiritual manusia kepada Tuhannya, sedangkan secara lahir, zakat itu merupakan pajak yang merupakan komitmen sosial sesama manusia. Oleh karena itu, orang yang membayar pajak harus diniati membayar zakat. Dengan demikian dua kali pengeluaran (double tax) yang selama ini menjadi permasalahan klasik di masyarakat akan terselesaikan.

Masdar mengritik praktik zakat selama ini yang dinilainya memiliki tiga kelemahan dasar: Pertama, kelemahan pada segi filosofi atau epistemologinya. Kelemahan ini ditandai oleh tidak adanya pandangan sosial yang mendasari praktik zakat, alias dogmatis a sosial. Zakat hanya dipandang sekadar amaliah ritual yang terpisah dari konteks sosial apapun. Zakat hanya merupakan santunan karikatif yang bersentuhan dengan kebutuhan perorangan, dalam skala yang sangat terbatas. Hal ini, menurut Masdar, salah satunya didorong pandangan dominan umat Islam terhadap teologi dan paradigma sosialnya. Kedua, berkaitan dengan struktur dan tata laksana zakat (kelembagaannya). Misalnya, tentang konsep zakat itu sendiri, objek zakat atau harta yang harus dizakati, kadar zakat, waktu zakat, dan seterusnya. Berangkat dari pandangan keagamaan yang dogmatis itu, zakatpun kemudian dipahami secara formalistis a historis. Ketiga, terkait dengan aspek managemen operasionalnya.

Terhadap ketiga kelemahan ini, Masdar mengusulkan agar penyelesaiannya tidak tambal sulam, sebagaimana yang dilakukan selama ini, tetapi zakat harus dikembalikan sebagai cita agama kerakyatan. Hal ini bisa dilakukan melalui rekonstruksi filosofi sosial zakat dan akar-akar sejarah zakat pada masa Rasulullah. Menurut Masdar, zakat itu pada mulanya adalah upeti sebagaimana umumnya berlaku dalam praktik ketatanegaraan zaman dulu. Hanya saja, upeti yang secara nyata telah membuat rakyat miskin semakin tenggelam dalam kemiskinannya, dengan spirit 'zakat', lembaga upeti itu justru harus menjadi sarana yang efektif bagi pemerataan dan penyejahteraan kaum miskin. Dengan kata lain, lembaga upeti yang semula menjadi sumber kedhaliman, dengan spirit 'zakat' harus ditranformasikan menjadi wahana penciptaan keadilan.

Dengan demikian, menurut Masdar, dapat dipahami bahwa hubungan antara "zakat" sebagai konsep keagamaan (keruhanian), di satu pihak, dan "pajak" sebagai konsep keduniawian (baca: kelembagaan), di pihak lain, sama sekali bukanlah hubungan dualisme yang dikotomis, melainkan hubungan keesaan wujud yang dialektis. Zakat bukanlah sesuatu yang harus dipisahkan, diparalelkan, dan apalagi dipersaingkan dengan "pajak", melainkan justru merupakan sesuatu yang harus disatukan sebagaimana disatukannya roh dengan badan atau jiwa dengan raga. "Zakat" merasuk ke dalam "pajak" sebagai ruh dan jiwanya, sedangkan "pajak" memberi bentuk pada "zakat" sebagai badan atau raga bagi proses pengejawantahannya. Memisahkan zakat dari pajak adalah sama halnya dengan memisahkan spirit dari tubuhnya, memisahkan bentuk dari essensinya.

Gagasan menyatukan zakat dan pajak ini juga terdapat kelompok yang kontra di kalangan umat Islam sendiri. Kalangan umat Islam yang keberatan apabila zakat dan pajak diintegrasikan karena keduanya merupakan dua hal yang berbeda. Zakat diwajibkan menurut landasan agama, sedangkan pajak diwajibkan oleh negara dengan landasan non syar'i (bukan hukum agama). Ada kekhawatiran kalau zakat dimasukkan ke dalam pajak, kewajiban shar'i yang melekat dalam zakat tidak tertunaikan.

Pro dan kontra tentang integrasi zakat dengan pajak terutama berlatar belakang pada perbandingan dari sisi persamaan dan 
perbedaannya. Daud Ali (1988) menyebutkan beberapa aspek untuk menunjukkan perbedaan zakat dengan pajak: 1)Zakat adalah kewajiban agama yang ditetapkan Allah, sedangkan pajak adalah kewajiban negara yang ditentukan oeh pemerintah; 2)Wajib zakat adalah orangorang Islam, sedangkan yang wajib membayar pajak tidak hanya orang Islam saja tetapi seluruh warga negara Indonesia tanpa memandang agama; 3)Penerima zakat sudah tertentu kelompoknya, sedangkan yang berhak menikmati pajak adalah seluruh penduduk yang ada dalam suatu negara; 4)Sanksi tidak membayar zakat adalah dosa, sedangkn sanksi tidak membayar pajak hanya denda; 5) Zakat tidak mungkin dihapuskan karena merupakn Rukun Islam, sedangkan pajak mungkin saja diganti atau dihapuskan tergantung pada pertimbangan pemerintah dan keadaan suatu negara.

Adapun sisi persamaan Zakat dengan Pajak adalah: 1) Bersifat wajib dan mengikat atas harta penduduk suatu negeri, apabila melalaikannya akan terkena sanksi, 2) Zakat dan pajak harus disetorkan pada lembaga resmi agar tercapai efisiensi penarikan keduanya dan alokasi penyalurannya, 3) Dalam pemerintahan Islam, zakat dan pajak dikelola oleh negara, 4) Tidak ada ketentuan memperoleh imbalan materi tertentu di dunia dan (4) dari sisi tujuan ada kesamaan antara keduanya yaitu untuk menyelesaikan problem ekonomi yang terdapat di masyarakat.

Dalam penelusuran sejarah kebudayaan Islam, konsep zakat dalam ajaran Islam merupakan kewajiban yang kini dikenal sebagai pajak. Islam datang dan menawarkan konsep pajak sebagai (bernama) zakat. Pajak dalam makna zakat dalam pandangan Islam bukan untuk penguasa atau negara tetapi untuk rakyat kecil. Dalam konteks pajak sebagai zakat, penguasa atau negara harus sepenuhnya melayani rakyatnya dan dana yang dipungut harus dimanfaatkan sebesar-besarnya untuk kepentingan rakyat. Oleh karena itu seperti pada Khalifah Rasulullah dulu, negara yang sudah mewajibkan pajak tidak lagi harus membayar zakat. Argumen historis ini menguatkan bahwa ada persamaan esensi antara zakat dan pajak.

\section{Era Digital}

Secara normatif, sebenarnya sudah ada isyarat bahwa negara dituntut untuk terlibat aktif dalam mengelola zakat. Dalam alQur'an misalnya Q.S. al-Taubah ayat 103 menjelaskan urgensi zakat untuk diambil oleh para petugas (amil) zakat. Sementara dalam hadis disebutkan bahwa ketika Rasulullah saw mengutus Muadz bin Jabal ke Yaman untuk berdakwah, beliau berpesan bahwa jika masyarakat di sana telah menyatakan masuk Islam ada kewajiban yang harus dilaksanakan yakni salat dan zakat yang akan diambil dari orang kaya mereka dan akan diberikan kepada orangorang fakir. (Rahman Ritonga dan Zainuddin:2002).

Intervensi pemerintah dinilai sangat penting dalam pengelolaan zakat karena beberapa alasan: 1)Zakat bukanlah bentuk charity (derma) biasa, melainkan derma yang bersifat imperatif (wajib). Pemungutan zakat dapat bersifat memaksa karena mengikuti perintah Kitab Suci; 2) Negara merupakan satu-satunya otoritas yang mampu melakukan tindak pemaksaan terhadap warga negaranya; 3) Potensi zakat sangat besar dan baru tergali sebagian saja. Optimalisasi dalam menghimpun, mengelola dan mendistribusikan akan mampu dilakukan oleh pemerintah; 4)Zakat dapat membantu pencapaian sasaran pembangunan nasional; 5) Masuknya zakat ke dalam kontrol negara mengurangi potensi korupsi karena petugas pajak atau aparat negara akan bertindak lebih hati-hati dalam mengelola uang negara.

Era digital sekarang ini sangat kondusif bagi pemerintah/negara untuk berperan aktif secara maksimal dalam pengelolaan zakat dan pajak. Terlepas dari pilihan apakah reposisi (tax deductible) sebagaimana adanya sekarang sesuai UU Nomor 23 Tahun 2011 tentang Pengelolaan Zakat, ataukah integrasi (zakat sebagai pengurang pajak secara langsung/tax credit).

Beberapa hal yang menjadi kendala dalam efektivitas dan efisiensi pelayanan proses pembayaran zakat sebagai pengurang penghasilan wajib pajak sebagaimana dalam temuan hasil penelitian Elis dan Alan (2018)_, akan terselesaikan dengan menggunakan sistem digital.

Jika Pemerintah menciptakan suasana kondusif dalam memberlakukan zakat 
sebagai pengurang pajak maka para muzaki akan semakin bersemangat membayar zakatnya, sehingga jumlah muzaki akan meningkat. Hal ini berarti juga akan meningkatkan jumlah wajib pajak secara berlipat.

Masyarakat Indonesia secara statistik lebih banyak bekerja pada sektor informal. Biasanya orang yang bekerja pada sektor informal, tidak biasa bayar pajak, namun mereka tetap rajin membayar zakat. Jika tercipta suasana kondusif maka pembayaran zakat akan juga sekaligus mendata sebagai wajib pajak, karena proses membayar pajak dilakukan secara bersamaan dengan membayar zakatnya. Di sisi lain, beberapa hasil penelitian menyimpulkan bahwa masyarakat muslim lebih puas membayar zakat daripada membayar pajak. Kondisi seperti ini potensial jika pemerintah mengkondisikan dengan baik, zakat sebagai pengurang pajak dengan pengelolaan yang lebih professional dan transparan.

Kendali pemerintah dalam mengelola zakat secara utuh melalui kementerian keuangan, sebagaimana juga pajak merupakan kebutuhan mendesak yang perlu segera dipertimbangkan. Dengan cara ini, peluang zakat sebagai pengurang pajak akan semakin prospektif bahkan bisa sebagai alternatif kebijakan fiskal di Indonesia. Dengan sendirinya kekuatan ekonomi negara bertambah, karena ada zakat selain pajak.

\section{KESIMPULAN}

Berangkat dari berbagai persoalan yang muncul sekitar zakat dan pajak selama ini, bisa disimpulkan bahwa gagasan integrasi dalam pengelolaan zakat dan pajak menjadi kebutuhan mendesak.

Jika pengumpulan zakat terintegrasi dengan pajak maka potensi ekonomi yang tergali, akan maksimal. Melalui intervensi pemerintah secara penuh, pendayagunaan zakat dan pajak pun akan berjalan lebih baik karena unsur keadilan ekonomi dan pembangunan di masyarakat dikendalilan melalui satu pintu.

Gagasan integrasi menjadi solusi bagi umat islam yang selama ini memiliki beban kewajiban ganda. Dalam penelusuran sejarah Islam pun, pajak tidak lain adalah kewajiban warga negara serupa zakat.

\section{DAFTAR PUSTAKA}

Ali, M. D. (1988). Sistem ekonomi Islam: Zakat dan wakaf. Jakarta: UI Press.

Ali, N. M. (2006). Zakat sebagai instrumen dalam kebijakan fiskal. Jakarta: PT Raja Grafindo Persada.

Fauziah. (2012). Menejemen pengelolaan dana zakat, infaq, shodaqoh dan wakaf (Studi kasus pada Yayasan Lembaga Amil Zakat, Infaq, Shodaqoh dan Wakaf (Lazis dan Wakaf) Sabilillah Malang. Universitas Islam Negeri Maulan Malik Ibrahim. Malang

Hafidhudidin, D., dkk. (2008). The Power of zakat studi perbandingan pengelolaan zakat Asia Tenggara. UIN Malang Press, Malang

Hafiduddin, D. Sinergi Zakat dengan Pajak dalam Menyejahterakan Umat, makalah pada seminar di Dirjen Pajak, Jakarta 19 Agustus 2011 Kompilasi Hukum Ekonomi Syari'ah (KHES).

Hasan, M. A. (2006). Zakat dan infaq, salah satu solusi mengatasi problema sosial di Indonesia. Jakarta: Kencana.

Khan, M. A. (1983) Muhammad The Final Messenger: Lahore: Sh. Muhammad Ashraf Publisher.

Khan, M. A. (1989). Economic teachings of Prophet Muhammad: A select anthology of hadith literature on economics. Islamabad: Interational Institute of Islamic Economics.

Mas'udi, M. F. (1993) Agama keadilan: Risalah zakat (Pajak) dalam Islam, cet 3. Jakarta: P3M.

Mas'udi, M. F. (2010). Pajak Itu zakat: Uang Allah untuk kemaslahatan rakyat. Bandung: Mizan Media Utama.

Mufraini, M. A. (2006), Akuntansi manajemen zakat, mengomunikasikan kesadaran dan membangun jaringan. Jakarta: Kencana.

Muhammad. (2004). Dasar-dasar keuangan Islami. Yogyakarta: Ekonisia.

Qardawi, Y. (1999). al-Siyasah al-Shariyyah (Pedoman bernegara menurut perspektif Islam, tarjamah: Kathur Suhardi). Jakarta: Pustaka al-Kautsar.

Qardawi, Y. (2007). Hukum zakat. Bogor: Litera Antar Nusa

Rahardjo, M. D. (2003). Perspektif deklarasi Makkah menuju ekonomi Islam. Bandung: Mizan.

Sayyid, S. (1983). Fiqh al-Sunnah, Juz I. 
Beirut: Dar al-Fikr.

Sudirman, M. A. (2007). Zakat dalam pusaran arus modernitas. UIN Malang Press.

Undang-Undang Nomor 23 tahun 2011 tentang Pengelolaan Zakat. 
Hidayat \& Rusmiati / Sinergi Zakat dan Pajak sebagai Solusi Perbaikan ... 